\title{
Research of landfill leachate treatment based on anammox
}

\author{
Denghua $\mathrm{Wu}^{1 *}$ \\ ${ }^{1}$ School of Nature Science, Michigan State University, East Lansing, Michigan,48824, United States
}

\begin{abstract}
Landfill leachate has the characteristics of high ammonia nitrogen content, high concentration of organic matter and low carbon nitrogen ratio. Traditional biological treatment technology is difficult to meet the increasingly stringent emission standards. Ammonia nitrogen is the main pollutant in landfill leachate. The ammonia-nitrogen-rich leachate not only poses a threat to the surrounding environment, but also has adverse effects on the subsequent biological treatment of leachate. Anaerobic ammonium oxidation (Anammox) is a new biological denitrification technology, which has the advantages of high denitrification capacity and low energy consumption, and is suitable for the treatment of landfill leachate. This article from the process type, inhibiting factors and microbiology at home and abroad are reviewed in three aspects: the anaerobic ammonia oxidation treatment, the research progress of landfill leachate by analyzing the national environmental protection agency of leachate quality related data in the database, and combining previous research results, reveals the infiltration drain liquid ammonia nitrogen in the different conditions of concentration variation characteristics, for anaerobic ammonia oxidation treatment of landfill leachate to provide the reference for engineering applications.
\end{abstract}

\section{INTRODUCTION}

With the continuous development of economy and society and the increasing population, the amount of household garbage increases year by year. Landfill, as the main way of disposing domestic garbage, has the advantages of simple operation and mature technology. In the landfill process, landfill leachate generated by the water contained in garbage and rainfall scouring, fermentation and groundwater infiltration has the characteristics of high concentration of ammonia nitrogen and high concentration of organic matter, which is easy to produce secondary pollution to the surrounding environment. It has always been the focus in the field of sewage treatment. Traditional biochemical treatment technology is difficult to effectively treat the landfill leachate, and there are some problems such as high cost and high energy consumption by means of physico-chemical treatment. At present, the research on landfill leachate treatment at home and abroad mainly focuses on the late landfill leachate. As the discharge standards of landfill leachate in China become more and more strict, it is urgent to develop a new lowcost landfill leachate treatment technology.

Anaerobic ammonium oxidation (ANAMMOX) is a new denitrification process developed in the 1990s. Under anaerobic conditions, ANAMMOX USES ammonia and nitrous nitrogen as substrate to produce nitrogen and a small amount of nitrate nitrogen. Compared with the traditional nitrification and denitrification denitrification process, the Anammox process has the advantages of strong denitrification capacity, no need to supplement organic carbon sources and low energy consumption. This technology has strong engineering potential. In recent years, it has been gradually applied to the treatment of wastewater with high ammonia nitrogen and low $\mathrm{C} / \mathrm{N}$. In this paper, the research progress of treatment of late landfill leachate based on anAMmoxidation is discussed from the aspects of process type, influencing factors and microbiology.

\subsection{Type of process based on an AMmox}

Sewage main exist in ammonia nitrogen, nitrogen, and according to the measure such as Strous Anammox reaction (1.1) , to achieve Anammox reaction, shall have the corresponding proportion in the system of the nitrate nitrogen, in order to achieve Anammox process garbage leachate, need to get the system to provide the appropriate concentration of the nitrate nitrogen, at the same time to ensure the stability of anaerobic ammonia oxidation bacteria growth(Strous et al., 1998).

$1 \mathrm{NH} 4++1.32 \mathrm{NO} 2-+0.066 \mathrm{HCO} 3-+0.13 \mathrm{H}+\rightarrow 1$. $02 \mathrm{~N} 2+0.26 \mathrm{NO} 3-+0.066 \mathrm{CH} 2 \mathrm{O} 0.5 \mathrm{~N} 0.15+2$. $03 \mathrm{H} 2 \mathrm{O} \quad(1.1)$

\subsubsection{PN-ANammox combination process}

Part to the nitrosation of anaerobic ammonia oxidation (PN - ANAMMOX) combination process, before the ANAMMOX part, increase the parts nitrosation, will fill in the nitrosation parts of the ammonia nitrogen and nitrate nitrogen, output appropriate proportion of the nitrate nitrogen and ammonia nitrogen, on the organic matter in water consumption at the same time, guarantee

Author Email: wudenghu@msu.edu 
the stable operation of the subsequent anaerobic ammonia oxidation. The first part of the system is called the SHARON process(Shalini and Joseph, 2012). In the second stage, Anammox is effectively denitrified in a completely anaerobic environment. This process configuration is a relatively conventional process using Anammox for engineering application. Li used THE SBR reactor in the laboratory to explore the long-term stability of the PN-Anammox two-stage process for landfill leachate treatment(Li et al., 2014, Li et al., 2017). Miao constructed the PN-Anammox process with the SBR system, achieved partial nitrification in the first SBR system, and then added packing in the second SBR system to constitute SBBR(Sequencing biofilmbatch reactor) system, and achieved the removal of $95 \%$ of total nitrogen(Miao et al., 2016a).

\subsubsection{CANON process}

The bacteria involved in completing the nitrification and anammoxidation steps were autotrophic microorganisms, using the CANON process for Completely autotrophic nitrogen removalover Nitrite. The two were cultured in a separate reactor, and the whole process of autotrophic denitrification was realized by controlling the dissolved oxygen, $\mathrm{pH}$ value, temperature and other parameters in the reactor. For example, Zhang Fangzhai used the CANON process to treat late landfill leachate. In the long run, the total nitrogen removal rate reached $98.76 \%$. Anshidi added tourmaline packing to the Canon-SBR reactor for reinforcement, and the removal load reached $0.104 \mathrm{~kg} \mathrm{~N} / \mathrm{m} 3 / \mathrm{d}$ on the $192 \mathrm{nd}$ day of operation. Dan et al. started the CANON process using the SBR reactor, and strictly controlled the $\mathrm{pH}$ and temperature of the reactor to achieve the removal of $93 \%$ of total nitrogen.

\subsubsection{SNAD}

SNAD process (Simultaneous Partial Nitrification, Anammox and Denitrification) is an orderly process of three nitrogen removal steps in a single reactor through micro-oxygen intermittent aeration: (1) Ammoniaoxidizing bacteria convert partial nitrification of ammonia nitrogen to nitrous nitrogen; (2) The remaining ammonia nitrogen and the nitrous nitrogen generated in (1) can generate nitrogen and part nitrate nitrogen through the action of anaerobic ammonia-oxidizing bacteria; (3) Denitrifying bacteria reduce the nitrate produced in (2) to nitrogen. According to Equation (1.1), the theoretical denitrification efficiency of anAMmox is not $100 \%$, and about $10 \%$ nitrate nitrogen will be produced(Miao et al., 2016a). For example, Wang et al. started the SNAD process in SBR, explored the influence of different nitrogen loads and $\mathrm{C} / \mathrm{N}$ ratio processes, and established a model to evaluate the contribution rate of partial nitrification, anaerobic ammonia oxidation and denitrification(Wang et al., 2014).

\subsection{4 other process types}

The effect of refractory organic matter in landfill leachate on anAMmox process was effectively solved by advanced oxidation - anAMmox process. A multi-year landfill leachate treatment plant in Europe combines activated sludge, ultrafiltration with activated carbon adsorption and anAMmox, reducing methanol cost by $91 \%$ and sludge yield by $96 \%$ (Wang et al., 2014). Short-cut denitrification is a new way to provide nitrous nitrogen for anAMmox(Azari et al., 2017). In recent years, many researches have focused on short-cut denitrification and anammox treatment of landfill leachate. The main principle of using anAMmox process is to give full play to the strong denitrification ability of anammox bacteria, so many physicochemical and biological coupling anammox processes have been proposed gradually(Phan et al., 2017).

\subsection{The nitrogen in the leach}

\subsubsection{Migration and transformation of nitrogenous substances}

The ammonia nitrogen in leachate mainly comes from the hydrolysis and ammonification of nitrogen-containing organics(Jokela et al., 2002). Anaerobic bacteria or aerobic bacteria hydrolyze proteins into dipeptides and polypeptides through extracellular proteases, which are further hydrolyzed into amino acids under the action of peptidase, which form $\mathrm{CO} 2$, small molecular organic acids and NH4+ through deamination or decarboxylic acid. Part of the generated NH4+ is assimilated and utilized by microorganisms in the landfill environment as a nitrogen source, while the other part is converted to nitrite and nitrite ions by nitrification of nitrifying bacteria and nitrifying bacteria under aerobic conditions. Under facultative oxygen conditions, nitrate and nitrite ions are converted to nitrogen by denitrifying bacteria(Pivato and Gaspari, 2006). At the same time, under anaerobic conditions, an ammoxic bacteria can also use nitrite ions as the final electron acceptor to oxidize ammonium ions to nitrogen by anammoxic oxidation. In addition, ammonium ions, as electron acceptors, can also be used by heterotrophic denitrifying bacteria and reduced by biological dissimilation. Or it can be reduced by autotrophic denitrifying bacteria, such as thiobacillus denitrifying, using sulfur compounds and inorganic carbon compounds as energy and carbon sources for denitrification.

\subsubsection{Existing forms of ammonia nitrogen}

There are two forms of ammonia nitrogen in leachate, one is free ammonia (NH3) and the other is ammonium ion (NH4+). Although there was no significant difference between the two in terms of their contribution to ammonia concentration, there were significant differences in their toxicity and inhibition to microorganisms(Hazen and Wuertz, 2012). P. L. Mc Carty et al. found that the toxicity of free ammonia was much higher than that of ammonium 
ion in aqueous solution. When the concentration of free ammonia reaches $100 \mathrm{mg} / \mathrm{L}$, methane-producing microorganisms will be inhibited, while the concentration of ammonium ion will be inhibited to 3000 $\mathrm{mg} / \mathrm{L}($ Mckinney, 1961). In an aqueous solution, the following equilibrium exists between free ammonia and ammonium ions:

$\mathrm{NH} 4+=\mathrm{H}++\mathrm{NH} 3 \quad\left(\mathrm{Ks}=5.56 \times 10-10, \quad \mathrm{~T}=35^{\circ} \mathrm{C}\right)$

Figure 1 shows the change of the proportion of free ammonia and ammonium ions in ammonia nitrogen with $\mathrm{pH}$. It can be seen when the $\mathrm{pH}$ is less than 7 , the proportion of ammonium ions in ammonia nitrogen is nearly $100 \%$, and the free state ammonia is less than $0.5 \%$ of the total ammonia nitrogen, and the influence of $\mathrm{pH}$ is not significant. When $\mathrm{pH}$ reaches 8 , the proportion of free ammonia increases rapidly with the increase of $\mathrm{pH}$. When $\mathrm{pH}$ reaches above 10 , ammonia nitrogen mainly exists in the form of free state.

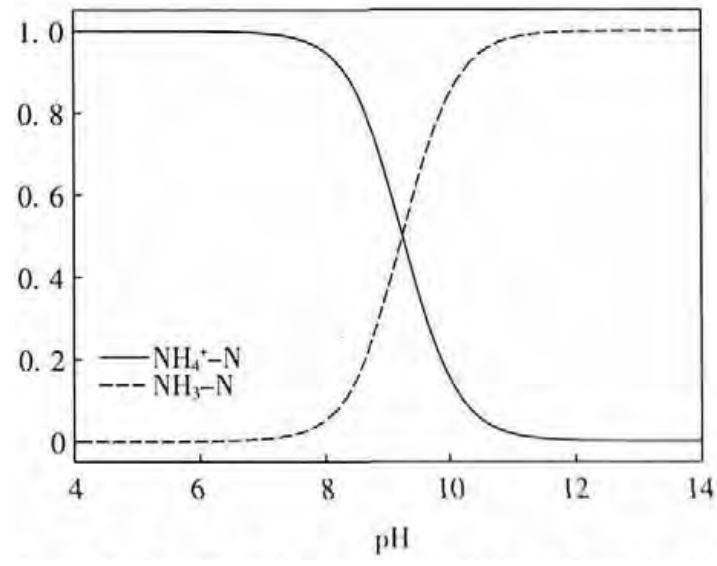

FIG. 1. The ratio of ammonium and free nitrogen in total nitrogen changes with $\mathrm{pH}$

\section{METHOD}

The database cited in this paper is from the United States Environmental Protection Agency. The database was established from 1997 to 2000 and mainly recorded the pollution index data of leachate in some landfill sites in the United States from the early 1980s to the late 1990s. It includes more than 250 different types of landfills in the United States, such as domestic waste landfills, construction waste landfills and hazardous waste landfills, with a total pollution index data of more than 450,000 . The main purpose of establishing this database is to unify the pollution index of landfill leachate and provide the real and reliable landfill information for researchers.

The influence of garbage composition Municipal solid waste and construction waste are the main components of municipal solid waste. Domestic garbage contains a large number of biodegradable organic matter, textiles, plastics, sawdust, rubber, waste paper, glass, etc. Construction waste mainly includes construction waste, waste bricks, waste tiles, waste concrete and scattered mortar, in addition to a small amount of steel, wood, glass, plastic, a variety of packaging materials. The difference in composition leads to the difference in the concentration of ammonia nitrogen in leachate of municipal solid waste landfill and construction waste landfill. Table 1 lists the types of some landfills in the United States and the concentration of ammonia nitrogen in leachate. Compared with domestic waste, construction waste has less biodegradable components, so the ammonia nitrogen content in landfill leachate is much lower than that of domestic waste landfill leachate.

Table 1. Types of landfill sites in the United States and their concentrations of ammonia nitrogen in leachate

\begin{tabular}{ccc}
\hline Type of landfill & $\begin{array}{c}\text { Number of } \\
\text { samples }\end{array}$ & $\begin{array}{c}\text { Ammonia } \\
\text { concentration/(mg/L) }\end{array}$ \\
\hline Arbor Hills (Living garbage) & 8 & $36 \sim 240$ \\
Bigfoot (Living garbage) & 34 & $32 \sim 1100$ \\
C\&C (Living garbage) & 27 & $14 \sim 680$ \\
Green Tree (Living garbage) & 12 & $13 \sim 280$ \\
Rockford (Living garbage) & 42 & $235 \sim 800$ \\
Ridgeville Site (Construction & 5 & $29 \sim 161$ \\
Brandy (Construction waste) & 1 & 1.40 \\
Deep R. (Construction waste) & 1 & 3.75 \\
LOWA\#4 (Construction waste) & 1 & 18.40 \\
LOWA\#5 (Construction waste) & 1 & 40.00 \\
WMNA (Construction waste) & 1 & \\
\hline
\end{tabular}


FIG. 2 shows the comparison of ammonia nitrogen concentration in leachate of domestic garbage and construction waste landfill sites (there are 375 domestic garbage data, which are derived from leachate database and some Chinese domestic garbage landfill sites; There were 18 construction waste data from leachate database. Figure 3 shows that the concentration of ammonia nitrogen in leachate of construction waste is 1 order of magnitude lower than that of domestic waste. The average concentration of ammonia nitrogen in domestic garbage landfill is close to $200 \mathrm{mg} / \mathrm{L}$, most of which are concentrated in $60 \sim 300 \mathrm{mg} / \mathrm{L}$. However, the average concentration of ammonia nitrogen in construction waste landfills is only $20 \mathrm{mg} / \mathrm{L}$, most of which are less than $50 \mathrm{mg} / \mathrm{L}$.

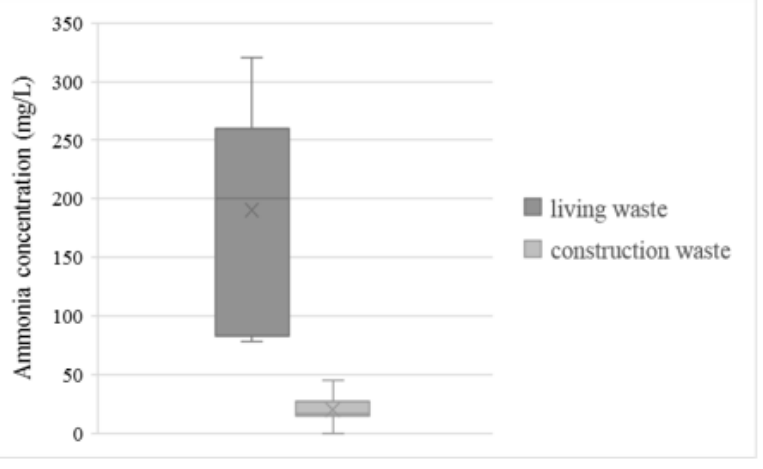

FIG. 2 Comparison of ammonia nitrogen concentration in leachate of household garbage and construction waste landfill site

Due to the differences in the composition of MSW in different regions/countries, the concentration of ammonia nitrogen in leachate of MSW landfill will also be different. Generally urban household waste in low - and middleincome countries contains a higher proportion of biodegradable organic matter, so the concentration of ammonia nitrogen is high. In high-income countries, the content of biodegradable organic matter is relatively low, and the concentration of ammonia nitrogen is relatively low. Table 2 lists the component content of domestic garbage in China and the United States. Organic matter in American domestic garbage only accounts for $13.9 \%$, which is much less than the 52.6 percent of organic waste in China. FIG. 4 shows the distribution of ammonia nitrogen concentration in leachate in landfill sites in China and the United States (26 Chinese data were collected from 17 literatures; There are 210 U.S. data from leachate database). It can be seen from Figure 4 that the average concentration of ammonia nitrogen in leachate of landfill in China is about $500 \mathrm{mg} / \mathrm{L}$ and mainly concentrates in the range of $300 \sim 1,600 \mathrm{mg} / \mathrm{L}$. The concentration of ammonia nitrogen in leachate in American landfills is also relatively low, with an average concentration of about $200 \mathrm{mg} / \mathrm{L}$ and mainly concentrated below $500 \mathrm{mg} / \mathrm{L}$.

Table 2. Composition of domestic waste in China and the United States

\begin{tabular}{ccc}
\hline component & $\begin{array}{c}\text { China(Zhang } \\
\text { et al., 2010) }\end{array}$ & America \\
\hline Degradable waste & 52.6 & 13.9 \\
Paper, cardboard, & 6.9 & 28.5 \\
plastic & 7.3 & 12.4 \\
glass & 1.6 & 4.6 \\
Metal material & 0.5 & 9 \\
textile & 4.7 & 8.4 \\
wood & 6.9 & 6.4 \\
others & 19.2 & 16.8 \\
\hline
\end{tabular}

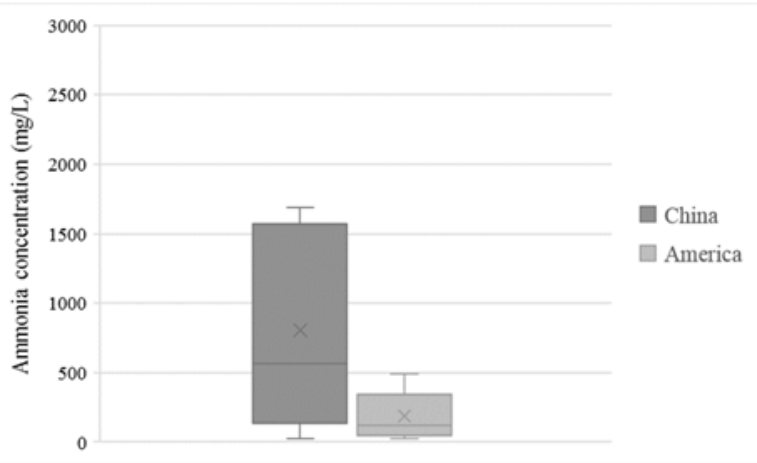

FIG. 3 Comparison of ammonia-nitrogen concentrations of Leachate in Chinese and American landfill sites

Landfill stabilization is a long - term process. According to foreign reports, it takes close to or even more than 100 landfill sites to achieve stability. In the whole process of landfill, the composition, content and nature of garbage will change, which leads to different characteristics of ammonia nitrogen concentration in different stages of leachate(El-Fadel et al., 1997). Table 3 shows the concentrations of ammonia nitrogen in leachate at different landfill stages. In general, the leachate has the characteristics of higher ammonia concentration in the fresh leachate and lower liquid pairs in the middle-aged and old leachate.

Table 3 Ammonia nitrogen concentration in landfill leachate in some countries and regions

\begin{tabular}{ccccc}
\hline National (regional) & stage & $\begin{array}{c}\text { ammonia nitrogen } \\
(\mathrm{mg} / \mathrm{L})\end{array}$ & landfill & type \\
\hline Hong Kong, China & young & 3000 & $\begin{array}{c}\text { Sai Tso Wan } \\
\text { Landfill }\end{array}$ & living waste \\
Thessaloniki, Greece & young & $1400 \sim 10250$ & - & living waste \\
Rome, Italy & young & 3917 & - & $\begin{array}{c}\text { industry } \\
\text { waste }\end{array}$ \\
Izmir, Turkey & young & $1120 \sim 2500$ & Harmandali landfill & living waste
\end{tabular}




\begin{tabular}{|c|c|c|c|c|}
\hline Istanbul, Turkey & young & 2160 & $\begin{array}{l}\text { Komurcuoda } \\
\text { landfill }\end{array}$ & living waste \\
\hline South Korea & young & $1635 \sim 1810$ & Kyungjoo landfill & living waste \\
\hline South Korea & young & $800 \sim 2200$ & CheongJu landfill & living waste \\
\hline Thessaloniki, Greece & Middle age & $40 \sim 1750$ & - & living waste \\
\hline Slovenia & Middle age & 642 & Artificial wetland & living waste \\
\hline Italy & Middle age & 1330 & TreMonti landfill & living waste \\
\hline Izmir, Turkey & Middle age & 1270 & Harmandali landfill & living waste \\
\hline $\begin{array}{c}\text { Should be } \\
\text { Buckingham }\end{array}$ & Middle age & $214 \sim 812$ & Calvert landfill & living waste \\
\hline Taiwan, China & aging & $180 \sim 201$ & - & living waste \\
\hline Poland & aging & 743 & Lipowka landfill & living waste \\
\hline Espoo, Finland & aging & $53 \sim 270$ & Gulf Coast landfill & living waste \\
\hline Florida, USA & aging & $53 \sim 744$ & $\begin{array}{l}\text { Indian River } \\
\text { County landfill }\end{array}$ & living waste \\
\hline Florida, USA & aging & $213 \sim 478$ & $\begin{array}{l}\text { Hillsborough } \\
\text { Height landfill }\end{array}$ & living waste \\
\hline $\begin{array}{c}\text { Rio DE Janeiro, } \\
\text { Brazil }\end{array}$ & aging & $250 \sim 374$ & Granmacho landfill & living waste \\
\hline
\end{tabular}

The ammoniacal nitrogen concentration of leachate in traditional sanitary landfill will increase rapidly in the early stage and decrease slowly in the later stage. Liu Jianying et al. conducted a study on the Shanghai Laogang landfill site and found that within the first 500 days of landfill, the concentration of ammonia nitrogen in leachate rapidly increased to more than $2500 \mathrm{mg} / \mathrm{L}$, and even as high as about $4,500 \mathrm{mg} / \mathrm{L}$. Table 4 shows the change of ammonia nitrogen concentration in leachate after 1.5 a in Shanghai Laogang landfill site. After 500 days, the ammonia concentration of leachate gradually decreased, and by the 8th year of landfill, the ammonia concentration had decreased to $180 \mathrm{mg} / \mathrm{L}$.

Table 4. Changes of ammonia nitrogen concentration in Leachate of Shanghai Laogang Landfill site

\begin{tabular}{cccccccc}
\hline $\begin{array}{c}\text { Landfill } \\
\text { time/a }\end{array}$ & 1.5 & 2 & 3.3 & 5 & 6 & 7 & 8 \\
\hline $\begin{array}{c}\text { ammonia } \\
\text { nitrogen } \\
(\mathrm{mg} / \mathrm{L})\end{array}$ & 621.03 & 383.27 & 457.63 & 437.24 & 284.56 & 206.81 & 180.22 \\
\hline
\end{tabular}

Under the traditional sanitary landfill method, the change of ammoniacal nitrogen concentration in leachate is mainly affected by the dissolution rate of nitrogenous substances in garbage, microbial utilization rate, adsorption of ammonium ions by garbage particles and precipitation complex. In the early stage of landfill, the dissolution rate of nitrogenous substances in garbage was higher than the utilization rate of microorganisms, leading to the rapid accumulation of ammonia nitrogen concentration to a higher level. The ammoniacal nitrogen concentration is higher in the early stage of landfill, which is also related to the $\mathrm{pH}$ of leachate(Pivato and Gaspari, 2006)

In the early stage of acid production, the $\mathrm{pH}$ of leachate is low, and $\mathrm{H}+$ will exchange with $\mathrm{NH} 4+$ adsorbed on the garbage particles, so that more $\mathrm{NH} 4+$ will enter in the leachate, leading to a higher concentration of ammonia nitrogen in the acid production stage. With the appearance of high concentration ammonia nitrogen environment, microorganisms that can make use of ammonia nitrogen show their survival advantages in number of microorganisms living together, which is conducive to the degradation of ammonia nitrogen and the reduction of its concentration. In addition, ammonia nitrogen can react with some substances to form waterinsoluble and biodegradable complexes, and can also be converted into components in humic acid, thus reducing the concentration of ammonia nitrogen in leachate.

Although ammonia nitrogen concentration will decrease with the extension of landfill time, due to the proportional relation of microbial growth and reproduction to the main nutrient elements of carbon, nitrogen and phosphorus, the ammonia nitrogen concentration decreases with time much more slowly than 
the mass concentration of COD and BOD. According to relevant literature, it takes at least 70 years or even hundreds of years for the concentration of ammonia nitrogen in leachate to decay to the level 1 discharge concentration (25 mg/L) (Yangfei et al., 2012). Therefore, the high concentration of ammonia nitrogen in leachate will be a long-term threat to the surrounding environment and groundwater.

\section{DISCUSSION}

\subsection{Impacts of landfill technology}

At present, majority of landfill sites adopt the traditional sanitary landfill. Under the traditional sanitary landfill method, the entrapment of oxygen in the landfill process takes place in an aerobic environment for a short time at the initial stage of its formation, and then enters an anaerobic state for a long time after the depletion of the entrapment(Miller, 1961). The slow hydrolysis of protein in conventional sanitary landfills makes the release of ammonia nitrogen from landfills last for a long time. According to a report by the UK Department of the Environment, almost $100 \%$ of the nitrogen in solid waste under conventional landfill will eventually be leachated as ammonia. $10 \%$ of the nitrogen will be quickly released into the leachate, and the rest will be gradually released over a long period of time(Townsend et al., 1996). While with the passage of time, the concentration of ammonia nitrogen in leachate can present a certain degree of decline, but relative to the city life sewage, leachate still high ammonia nitrogen concentration, usually in the hundreds of $\mathrm{mg} / \mathrm{L}$, at the same time as the organic matter in leachate gradually reduce, aged leachate will present the characteristics of low $\mathrm{C} / \mathrm{N}$, which causes the difficulty in subsequent biological treatment. Therefore, under the traditional sanitary landfill method, leachate ammonia nitrogen is one of the main long-term threats.

Anaerobic bioreactor landfill is a landfill technology developed based on traditional sanitary landfill method. Its core is to strengthen the biological process of microorganism in landfill through leachate recharging or adding other substances, to accelerate the decomposition of organic components in landfill and the stability of landfill site. However, due to the lack of the necessary biological denitrification pathway, the concentration of ammonia nitrogen in leachate will increase with the degradation of landfill waste and the circulation of leachate, and even make the concentration of ammonia nitrogen in the leachate in the later period higher than that in the traditional sanitary landfill.

In anaerobic landfill, ammonia nitrogen is easy to accumulate and attenuates slowly. Landfill ventilation is an important way to solve the problem of excessive ammonia nitrogen concentration in anaerobic landfill. Aeration can create an aerobic zone in the garbage layer. In the aerobic environment, the activity of nitrifying bacteria is enhanced. Ammonia nitrogen can be converted to nitrate and nitrous nitrogen by nitrification, which can be further converted to nitrogen by denitrifying bacteria, thus reducing the concentration of ammonia nitrogen in leachate.

According to different ventilation modes, it can be divided into forced ventilation aerobic landfill and quasiaerobic landfill. Forced ventilation and aerobic landfill is a landfill method that uses air blast equipment to ventilate and supply oxygen to the landfill layer(Townsend et al., 1996). By using the non-uniformity or intermittent aeration of the waste layer in space, the waste layer can present aerobic zone, anaerobic zone and anaerobic zone simultaneously. When the leachate flows through these areas, nitrification and denitrification can be carried out in turn, so as to reduce the concentration of ammonia nitrogen in the leachate(Onay and Pohland, 1998). T. T. Onay et al. aerated at the bottom of the landfill, and created anoxic, anaerobic and aerobic zones from top to bottom in the landfill. Through leachate circulation, 95\% ammonia nitrogen could be transformed and removed. Through intermittent aeration at the bottom of the landfill, L. M. Shao et al. created a dynamic aerobic-anaerobicanaerobic environment in the garbage layer, which greatly reduced the concentration of ammonia nitrogen in leachate while still maintaining a low concentration of nitrate nitrogen(Shao et al., 2008).

Quasi-aerobic landfill is a widely used domestic garbage disposal method in Japan. It uses the non-full flow design of leachate collection pipe to make the air naturally enter the garbage under the push of the temperature difference caused by the fermentation of the landfill body, and forms a certain aerobic area in the landfill site. In aerobic environment, the activity of nitrifying bacteria was enhanced, and ammonia nitrogen was converted to nitrate and nitrous nitrogen by nitrification, which were further converted to nitrogen by denitrifying bacteria, thus reducing the concentration of ammonia nitrogen in leachate. In addition, the proportion of nutrients in quasi-aerobic landfill is coordinated, and BOD5/COD is relatively high. Such an environment is conducive to the survival of microorganisms and the exertion of their activity, thus making the concentration of ammonia nitrogen show a downward trend.

\subsection{The influencing factors of anAMmox}

Obviously, the anammox part plays a decisive role in the above combination process. Anammox is a kind of autotrophic bacteria with long doubling time and relatively harsh growth conditions. The presence of heavy metal ions, high concentration of organic matter and dissolved oxygen in landfill leachate may inhibit the activity of anammox.

\subsubsection{Substrate concentration and load}

The results show that the presence of too much free ammonia and free nitrite in the system will inhibit the anaerobic ammonia oxidation process, and too much cumulative nitrogen load will also inhibit the anaerobic ammonia oxidation process(Ganigu and Technology, 2010). Ruscalleda et al. believed that controlling the ratio of nitrous nitrogen to ammonia nitrogen was the key to 
maintain the balance between anAMmoxic bacteria and other strains(Lotti et al., 2012). This rule is the same as that found by Lotti et al. when doing basic research. However, Lotti et al. believe that the effect of nitrous oxide on anAMmox is reversible, rather than a lethal toxic effect. Systems such as Phan work well with NLR up to $10 \mathrm{~kg} \mathrm{~N} / \mathrm{m} 3 / \mathrm{d}$ and have a nitrogen removal rate of over 95\%(Phan et al., 2017).

\subsubsection{The organic matter}

Anammox is a kind of autotrophic bacteria, and organic matter has been regarded as an important growth inhibiting factor(Tang et al., 2010). However, other studies have shown that the presence of appropriate amount of organic matter in the system is conducive to maintaining the balance between denitrifying bacteria and anaerobic ammox bacteria, thus improving the denitrification capacity of the whole system(A et al., 2014). Many studies have found that organic matter has limited influence on Anammox treatment of landfill leachate. Wang et al. found that Anammox did not significantly affect the denitrification effect of landfill leachate when the COD concentration exceeded $2000 \mathrm{mg} / \mathrm{L}$ (Miao et al., 2016b). The composition of landfill leachate is complex and the organic matter is difficult to be biodegraded. In order to recover the anAMMOx system from matrix shock or organic shock, studies have been conducted to mix low-concentration wastewater into landfill leachate (such as municipal sewage), so that the system can continue to maintain a certain treatment capacity.

\subsubsection{PH, dissolved oxygen and temperature}

$\mathrm{PH}$, dissolved oxygen and temperature are the common factors affecting the activity of anAMmox. When the factors in landfill leachate fluctuate greatly, they will affect the treatment effect of the whole process. In practical application, the above factors need to be controlled to some extent. PH will directly affect the growth activity of various bacteria in the system, and also affect the direct chemical balance of ammonia and free ammonia with nitrous and free nitrite. The optimum $\mathrm{pH}$ of anAMmoxic bacteria was $6.5 \sim 8.8$ (Oshiki et al., 2011). Anammox is a strict anaerobe and is inhibited when the dissolved oxygen exceeds $0.5 \%$ saturation. The concentration of dissolved oxygen in the system is adjusted according to the type of process and with changes in inlet water quality. In addition, researchers generally believe that the optimal growth temperature of anAMmoxic bacteria is $35 \sim 40{ }^{\circ} \mathrm{C}$.

\subsubsection{Salinity and metal ions}

High salinity is an important characteristic of late landfill leachate, and anaerobic ammoniacal bacteria exist widely in nature. Metal ion is a common factor affecting microbial activity in sewage treatment. In addition to the common metal elements $\mathrm{Ca} 2+, \mathrm{Mg} 2+, \mathrm{Fe} 2+$, etc., the landfill leachate may also contain heavy metals such as
$\mathrm{Cd}$ and $\mathrm{Hg}$. However, the influence of heavy metal ions on the treatment of landfill leachate by Anammox is not common at present.

\section{CONCLUSION}

The discharge standard of landfill leachate is becoming more and more stringent, and the demand for energy saving and consumption reduction is increasing day by day. It is a feasible way to treat landfill leachate by anAMmox. Some progress has been made in the research over the years, which advances the engineering application of anAMmox technology. As a new biotechnology, anAMMOx still has many engineering problems that need to be solved urgently, such as the technical key of long-term stable operation, the elimination of influencing factors and the mechanism of microbial action.

The difference of landfill components will lead to the difference of ammonia nitrogen concentration in leachate. The higher the content of easily degraded organic matter, the higher the concentration of ammonia nitrogen in leachate. In general, landfill leachate concentrations in low - and middle-income countries are higher than in developed countries. Meanwhile, compared with domestic waste landfill, the leachate concentration of construction waste landfill is 1 order of magnitude lower.

For traditional sanitary landfill, the concentration of ammonia in fresh leachate is high, while that in old leachate is relatively low. In the early stage of landfill, ammonia concentration increases rapidly. The concentration of ammonia nitrogen decreased slowly with the extension of landfill time.

In traditional sanitary landfill and anaerobic bioreactor landfill, the concentration of ammonia nitrogen in leachate is always at a high level. However, in aerobic and quasi-aerobic landfills, leachate ammonia nitrogen can be removed by nitrification - denitrification process, making its concentration significantly lower than that in conventional sanitary landfills and anaerobic bioreactor landfills.

\section{References}

1. A, S. J., B, S. E. V., C, E. M. A. \& A, K. M. U. J. W. R. 2014. Successful application of nitritation/anammox to wastewater with elevated organic carbon to ammonia ratios. 49, 316-326.

2. AZARI, MOHAMMAD, REKERS, VOLKER, DENECKE, MARTIN, JI-DONG, WALTER, TOXICOLOGY, U. J. C. E. \& ASSESSMENT, R. 2017. More than a decade of experience of landfill leachate treatment with a full-scale anammox plant combining activated sludge and activated carbon biofilm. 174, 117-126.

3. EL-FADEL, M., FINDIKAKIS, A. N., LECKIE, O. J. W. M. \& RESEARCH 1997. NUMERICAL MODELLING OF GENERATION AND TRANSPORT OF GAS AND HEAT IN 
SANITARY LANDFILLS III. SENSITIVITY ANALYSIS. 15, 87-102.

4. GANIGU, R.-G., J. - LPEZ, H. - RUSCALLEDA, M. - BALAGUER, M. D. - COLPRIM, J \%J WATER ENCE \& TECHNOLOGY 2010. Combining partial nitritation and heterotrophic denitritation for the treatment of landfill leachate previous to an anammox reactor. 61, p.1949-1955.

5. HAZEN, T. C. \& WUERTZ, S. J. C. O. I. B. 2012. Environmental biotechnology. 23.

6. JOKELA, J. P. Y., KETTUNEN, R. H., SORMUNEN, K. M. \& RINTALA, J. A. J. W. R. 2002. Biological nitrogen removal from municipal landfill leachate: low-cost nitrification in biofilters and laboratory scale in-situ denitrification. 36, 40794087.

7. LI, H., ZHOU, S., MA, W., HUANG, P., HUANG, G., QIN, Y., XU, B. \& OUYANG, H. J. B. T. 2014. Long-term performance and microbial ecology of a two-stage PN-ANAMMOX process treating mature landfill leachate.

8. LI, Y., LI, J., ZHAO, B., WANG, X., ZHANG, Y., WEI, J. \& BIAN, W. J. E. T. 2017. A coupled system of half-nitritation and ANAMMOX for mature landfill leachate nitrogen removal. 38, 2335-2343.

9. LOTTI, T., STAR, W. R. L. V. D., KLEEREBEZEM, R., LUBELLO, C. \& LOOSDRECHT, M. C. M. V. J. W. R. 2012. The effect of nitrite inhibition on the anammox process. $46,2559-2569$.

10. MCKINNEY, M. C. E. J. J. 1961. Salt Toxicity in Anaerobic Digestion. 33, 399-415.

11. MIAO, LEI, LIU, ZHAOYUAN, ZHANG, MAN, WANG, SHUYING, PENG \& YONGZHEN \%J BIORESOURCE TECHNOLOGY: BIOMASS, B., BIOWASTES, CONVERSION TECHNOLOGIES, BIOTRANSFORMATIONS, PRODUCTION TECHNOLOGIES 2016a. Advanced nitrogen removal from landfill leachate via Anammox system based on Sequencing Biofilm Batch Reactor (SBBR): Effective protection of biofilm.

12. MIAO, LEI, WANG, SHUYING, ZHONG, ZHANG, FANGZHAI, HAN, JINHAO \& TECHNOLOGIES, P. J. B. T. B. B. B. C. T. B. P. 2016b. Continuousflow combined process of nitritation and ANAMMOX for treatment of landfill leachate.

13. MILLER, B. H. 1961. Ammonia gas dynamics in four Vancouver area landfills.

14. ONAY, T. T. \& POHLAND, F. G. J. W. R. 1998. In situ nitrogen management in controlled bioreactor landfills. 32, 1383-1392.

15. OSHIKI, M., SHIMOKAWA, M., FUJII, N., SATOH, H. \& OKABE, S. J. M. 2011. Physiological characteristics of the anaerobic ammonium-oxidizing bacterium 'Candidatus Brocadia sinica'. 157, 1706.

16. PHAN, T. N., VAN TRUONG, T. T., HA, N. B., NGUYEN, P. D., BUI, X. T., DANG, B. T., DOAN, V. T., PARK, J., GUO, W. \& NGO, H. H. J. B. T. 2017. High rate nitrogen removal by ANAMMOX internal circulation reactor (IC) for old landfill leachate treatment. 234, 281.

17. PIVATO, A. \& GASPARI, L. J. W. M. 2006. Acute toxicity test of leachates from traditional and sustainable landfills using luminescent bacteria. 26, 1148-1155.

18. SHALINI, S. S. \& JOSEPH, K. J. W. M. 2012. Nitrogen management in landfill leachate: Application of SHARON, ANAMMOX and combined SHARON-ANAMMOX process. 32, 2385-2400.

19. SHAO, L. M., HE, P. J. \& LI, G. J. J. W. M. 2008. In situ nitrogen removal from leachate by bioreactor landfill with limited aeration. 28, 1000-1007.

20. STROUS, M., HEIJNEN, J. J., KUENEN, J. G., JETTEN, M. S. M. J. A. M. \& BIOTECHNOLOGY 1998. The sequencing batch reactor as a powerful tool for the study of slowly growing anaerobic ammonium-oxidizing microorganisms. 50, 589-596.

21. TANG, C. J., PING, Z., WANG, C. H. \& MAHMOOD, Q. J. B. T. 2010. Suppression of anaerobic ammonium oxidizers under high organic content in high-rate Anammox UASB reactor. 101, 1762-1768.

22. TOWNSEND, T. G., MILLER, W. L., LEE, H. J. \& EARLE, J. F. K. J. J. O. E. E. 1996. Acceleration of Landfill Stabilization Using Leachate Recycle. 122.

23. WANG, C. C., LEE, P. H., KUMAR, M., HUANG, Y. T., SUNG, S. \& LIN, J. G. J. J. O. H. M. 2014. Simultaneous partial nitrification, anaerobic ammonium oxidation and denitrification (SNAD) in a full-scale landfill-leachate treatment plant. 175, 622-628.

24. YANGFEI, YANG, YUE, QIFEI, MANAGEMENT, H. J. W., WASTES, R. T. J. O. T. I. S. \& ISWA, P. C. A. 2012. Influence of semi-aerobic and anaerobic landfill operation with leachate recirculation on stabilization processes.

25. ZHANG, D. Q., TAN, S. K. \& GERSBERG, R. M. J. J. O. E. M. 2010. Municipal solid waste management in China: Status, problems and challenges. 91, 16231633. 